\title{
Pengaruh Motivasi Belajar Terhadap Kemampuan Membaca Pemahaman Mahasiswa STBA-PIA Semester 5
}

\author{
Cynthia Hualangi \\ STBA-PIA, Medan, Sumatera Utara \\ Jonathan Effendy \\ STBA-PIA, Medan, Sumatera Utara
}

\begin{abstract}
The aim of this research was to find whether learning motivation had a significant effect on the $5^{\text {th }}$ semester of STBA-PIA students' reading comprehension in Mandarin. This research applied ex post facto design and random sampling. The population of this study was 170 students majoring in Chinese Literature at STBA-PIA in academic year 2013/2014. The sample was 50 students. The data was collected by using questionnaire to find their learning motivation and HSK 5 test. The data was analysed by using validity test, reliability test, data description and ttest. This study showed that $\mathrm{t}_{\text {count }}$ was 7.674 and $\mathrm{t}_{\text {table }}(\mathrm{dk}=48)$ was 1.67. The $t_{\text {count }}>t_{\text {table }}(7.674>1.67)$ which showed that there was a significant effect of learning motivation on the $5^{\text {th }}$ semester STBA-PIA students' reading comprehension in which the significant level was 5\%. Ha was accepted while Ho was rejected.
\end{abstract}

Keywords: learning motivation, reading comprehension, Chinese literature

\section{Pendahuluan}

Membaca adalah suatu proses yang mengacu pada aktivitas mental dan fisik yang melibatkan 3 hal pokok, yaitu: pengetahuan yang dimiliki oleh pembaca mengenai topik bacaan, pengetahuan pembaca tentang struktur teks, dan kegiatan menemukan makna teks atau bacaan secara keseluruhan. Tujuan dari membaca tidak hanya sekedar untuk mempraktekkan kemampuan pelafalan kata-kata dengan baik. Pada tingkatan yang lebih tinggi, membaca bertujuan untuk mendapatkan makna pesan, informasi, fakta, atau ide pokok bacaan dengan baik, yang disebut dengan membaca pemahaman. Rubin (1982:106) mendefinsikan membaca pemahaman sebagai proses intelektual yang kompleks yang mencakup dua kemampuan utama, yaitu penguasaan makna kata dan kemampuan berpikir tentang konsep verbal.

Kemampuan memahami teks atau bacaan adalah salah satu kemampuan yang sangat dibutuhkan oleh setiap orang dalam kehidupan sehari-hari. Namun, kemampuan sesorang untuk memiliki kemampuan untuk memahami teks dipengaruhi oleh beberapa faktor. Alexander (1983:146) berpendapat bahwa faktor-faktor yang mempengaruhi 
pengembangan pemahaman bacaan meliputi: program pengajaran membaca, kepribadian siswa, motivasi, kebiasaan dan lingkungan sosial ekonomi mereka. Selain faktor-faktor diatas, adapun faktor lain yang merupakan faktor penyebab rendahnya kemampuan membaca seseorang dalam konteks indonesia adalah (1) tradisi kelisanan yaitu seperti di ketahui bahwa secara historis kultur masyarakat seseorang mengantongi warisan budaya lisan atau budaya tutur yang memfosil dan, (2) sistem persekolahan yang kurang memberikan peluang yang cukup bagi hadirnya tradisi keberaksaran atau tradisi membacakan bacaan kepada para peserta didik, seperti guru terlalu banyak menjadi pembicara dan murid terlalu banyak menjadi pendengar.

Dari beberapa faktor tersebut, peneliti akan berfokus pada hal yang terdapat di dalam diri subjek penelitian, yaitu motivasi belajar. Motivasi belajar adalah suata dorongan yang terdapat di dalam diri seseorang untuk mengupayakan suatu kegiatan atau pekerjaan dengan baik demi mendapatkan hasil yang maksimal atau memuaskan. Dalam proses pembelajaran, motivasi memiliki peranan yang sangat penting. Menurut Nashar (2004:11), motivasi belajar yang dimiliki peserta didik dalam setiap kegiatan pembelajaran sangat berperan untuk meningkatkan prestasi belajar peserta didik dalam mata pelajaran tertentu. Namun, dalam penelitian yang dilakukan oleh Wei (2007) disebutkan bahwa motivasi belajar siswa tidak memiliki hubungan yang signifikan dengan prestasi akademik bahasa Mandarin mereka.

Berdasarkan uraian di atas, penulis memandang perlu adanya penelitian tentang pengaruh motivasi belajar terhadap prestasi akademik bahasa Mandarin, khususnya pada kemampuan membaca pemahaman.

\section{Metode}

\section{Desain Penelitian}

Untuk mengetahui apakah motivasi belajar mempengaruhi kemampuan membaca pemahaman teks bahasa Mandarin mahasiswa STBA-PIA semester 5, maka peneliti menerapkan desain penelitian non-eksperimen jenis ex-post facto. Variabel penelitian ini adalah motivasi belajar yang di ukur dengan angket. Dan kemampuan membaca pemahaman dapat diperoleh dengan cara tes. Yang kemudian setiap jawaban sampel diberi nilai dalam bentuk angka.

\section{Populasi dan Sampel}

Populasi dalam penelitian ini berjumlah 170 orang. Sampel yang digunakan adalah simple random sampling yang berjumlah 50 orang atau $30 \%$ dari populasi. 


\section{Instrumen Penelitian}

Instrumen penelitian dalam penelitian ini adalah angket dan tes yang telah diberikan kepada sampel. Angket berisi 10 pertanyaan yang berhubungan dengan indikator motivasi. Sedangkan, tes digunakan untuk memperoleh nilai yang dapat digunakan sebagai indikator kemampuan membaca pemahaman.

\section{Hasil}

\section{Deskripsi Data}

Pertanyaan yang disusun terdiri dari 10 butir pertanyaan yang menjurus pada indikator motivasi belajar yaitu Motivasi Integratif dan Motivasi Instrumental. Pada kemampuan membaca pemahaman digunakan tes yang terdiri dari 20 butir soal yang merupakan soal HSK 5. Karakteristik motivasi belajar pada angket dapat dilihat seperti table di bawah ini.

Tabel 3.1 Kriteria Penafsiran Motivasi Belajar

\begin{tabular}{|c|c|}
\hline Interval & Kriteria \\
\hline $10-18$ & Sangat Tidak Setuju \\
\hline $18.1-26$ & Tidak Setuju \\
\hline $26.1-34$ & Sedang \\
\hline $34.1-42$ & Setuju \\
\hline $42.1-50$ & Sangat Setuju \\
\hline
\end{tabular}

Tabel 3.2 Mean, Median, Modus, standar deviasi, minimum dan maximum

Statistics

\begin{tabular}{|c|c|c|c|c|c|c|c|c|c|c|c|}
\hline & Q1 & $\mathrm{Q} 2$ & Q3 & Q4 & Q5 & Q6 & Q7 & Q8 & Q9 & Q10 & Total \\
\hline Valid & 50 & 50 & 50 & 50 & 50 & 50 & 50 & 50 & 50 & 50 & 50 \\
\hline Missing & 0 & 0 & 0 & 0 & 0 & 0 & 0 & 0 & 0 & 0 & 0 \\
\hline Mean & 3.84 & 4.06 & 4.18 & 3.66 & 3.80 & 3.80 & 3.62 & 3.92 & 3.82 & 3.76 & 38.46 \\
\hline Median & 4.00 & 4.00 & 4.50 & 4.00 & 4.00 & 4.00 & 4.00 & 4.00 & 4.00 & 4.00 & 39.00 \\
\hline Mode & 4.00 & 5.00 & 5.00 & 4.00 & 5.00 & 5.00 & 5.00 & 5.00 & 5.00 & 5.00 & 34.00 \\
\hline $\begin{array}{l}\text { Std. } \\
\text { Deviation }\end{array}$ & 1.167 & 1.096 & 1.063 & 1.062 & 1.278 & 1.125 & 1.260 & 1.140 & 1.224 & 1.318 & 6.649 \\
\hline Range & 4.00 & 4.00 & 4.00 & 4.00 & 4.00 & 3.00 & 4.00 & 4.00 & 4.00 & 4.00 & 27.00 \\
\hline Minimum & 1.00 & 1.00 & 1.00 & 1.00 & 1.00 & 2.00 & 1.00 & 1.00 & 1.00 & 1.00 & 22.00 \\
\hline Maximum & 5.00 & 5.00 & 5.00 & 5.00 & 5.00 & 5.00 & 5.00 & 5.00 & 5.00 & 5.00 & 49.00 \\
\hline
\end{tabular}

Sumber : data diproses menggunakan SPSS 22.0

Berdasarkan data motivasi belajar yang telah diproses menggunakan SPSS 22.0, dapat diketahui bahwa Mean dari motivasi belajar adalah 38.46 (setuju), median adalah 
39.00 (setuju) dan modus adalah 34.00 (sedang). Dengan standar deviasi sebesar 6.649 dan nilai tertinggi adalah 49.00 sedangkan untuk nilai terendah adalah 22.00

Tabel 3.3 Distribusi Frekuensi Motivasi Belajar

\begin{tabular}{|c|c|c|c|}
\hline No & Interval Kelas & Frekuensi & $\begin{array}{c}\text { Frekuensi Relatif } \\
(\%)\end{array}$ \\
\hline 1 & $22-25$ & 2 & $4 \%$ \\
\hline 2 & $26-29$ & 3 & $6 \%$ \\
\hline 3 & $30-33$ & 5 & $10 \%$ \\
\hline 4 & $34-37$ & 11 & $22 \%$ \\
\hline 5 & $38-41$ & 10 & $20 \%$ \\
\hline 6 & $42-45$ & 11 & $22 \%$ \\
\hline 7 & $46-49$ & 8 & $16 \%$ \\
\hline & Total & 50 & $100 \%$ \\
\hline
\end{tabular}

Tabel 3.4 Tingkat kecenderungan Motivasi Belajar

\begin{tabular}{|c|c|c|c|}
\hline No & Interval & Frekuensi & Kategori \\
\hline 1 & $22-30$ & 7 & Rendah \\
\hline 2 & $31-39$ & 19 & Sedang \\
\hline 3 & $\geq 40$ & 24 & Tinggi \\
\hline
\end{tabular}

\section{Karakteristik Kemampuan Membaca Pemahaman}

Tabel 3.5 Kriteria penafsiran kemampuan membaca pemahaman

\begin{tabular}{|c|c|}
\hline Interval & Kriteria \\
\hline $0-20$ & Sangat Rendah \\
\hline $21-40$ & Rendah \\
\hline $41-60$ & Sedang \\
\hline $61-80$ & Tinggi \\
\hline $81-100$ & Sangat Tinggi \\
\hline
\end{tabular}


Tabel 3.6 Mean, Median, Modus, standar deviasi, minimum dan maximum

Statistics

Ke mampuan Membaca

\begin{tabular}{|l|r|}
\hline $\mathrm{P} \quad \mathrm{e} \quad \mathrm{m} \quad \mathrm{a} \quad \mathrm{h}$ & $\mathrm{m} \quad \mathrm{alid}$ \\
\multicolumn{1}{|c}{ Missing } & 50 \\
Mean & 0 \\
Median & 79.2000 \\
Mode & 80.0000 \\
Std. Deviation & 90.00 \\
Range & 14.82414 \\
Minimum & 40.00 \\
Maximum & 60.00 \\
\hline
\end{tabular}

Sumber : data diproses menggunakan SPSS 22.0

Berdasarkan data kemampuan membaca pemahaman yang telah diproses menggunakan SPSS 22.0, dapat diketahui bahwa Mean adalah 79.2 (tinggi), median adalah 80 ( tinggi ) dan modus adalah 90.0 (tinggi). Dengan standar deviasi sebesar 14.824 dan nilai tertinggi adalah 100 sedangkan untuk nilai terendah adalah 60 .

Tabel 3.7 Distribusi Frekuensi kemampuan membaca pemahaman

\begin{tabular}{|c|c|c|c|}
\hline No & Interval Kelas & Frekuensi & $\begin{array}{c}\text { Frekuensi Relatif } \\
(\%)\end{array}$ \\
\hline 1 & $60-65$ & 9 & $18 \%$ \\
\hline 2 & $66-71$ & 8 & $16 \%$ \\
\hline 3 & $72-77$ & 0 & $0 \%$ \\
\hline 4 & $78-83$ & 12 & $24 \%$ \\
\hline 5 & $84-89$ & 0 & $0 \%$ \\
\hline 6 & $90-95$ & 15 & $30 \%$ \\
\hline 7 & 96-101 & 6 & $12 \%$ \\
\hline \multicolumn{2}{|r|}{ Total } & 50 & $100 \%$ \\
\hline
\end{tabular}

Tabel 3.8 Tingkat kecenderungan kemampuan membaca pemahaman

\begin{tabular}{|c|c|c|c|}
\hline No & Interval & Frekuensi & Kategori \\
\hline 1 & $60-72$ & 17 & Rendah \\
\hline 2 & $73-85$ & 12 & Sedang \\
\hline 3 & $\geq 86$ & 21 & Tinggi \\
\hline
\end{tabular}




\section{Data Analisis}

\section{Uji Validitas Kuesioner}

Uji coba dilakukan terhadap 10 responden dimaksudkan untuk menguji keabsahan dan kehandalan instrumen yang digunakan dalam penelitian. Validitas instrumen diuji menggunakan "Pearson's Product Moment". Kriteria pengujian dengan membandingkan antara $r_{\text {hitung }}$ dengan $r_{\text {tabel }}$ jika $r_{\text {hitung }}>r_{\text {tabel }}$ maka instrumen dianggap valid dan begitu pula sebaliknya (Sugiyono,2010).

Hasil perhitungan korelasi untuk skor setiap butir pertanyaan dengan skor total variabel motivasi belajar dapat dilihat dari tabel 3.9 berikut:

Tabel 3.9 Hasil Perhitungan Validitas

\begin{tabular}{|c|c|c|c|}
\hline \multicolumn{5}{|c|}{ Motivasi Belajar Bahasa (Variabel X) } \\
\hline No Butir & R hitung & R tabel $(\mathrm{n}=10 ; \alpha=0.05)$ & Kesimpulan \\
\hline 1 & 0.679 & 0.632 & Valid \\
\hline 2 & 0.736 & 0.632 & Valid \\
\hline 3 & 0.657 & 0.632 & Valid \\
\hline 4 & 0.659 & 0.632 & Valid \\
\hline 5 & 0.744 & 0.632 & Valid \\
\hline 6 & 0.654 & 0.632 & Valid \\
\hline 7 & 0.698 & 0.632 & Valid \\
\hline 8 & 0.686 & 0.632 & Valid \\
\hline 9 & 0.661 & 0.632 & Valid \\
\hline 10 & 0.643 & 0.632 & Valid \\
\hline
\end{tabular}

Berdasarkan hasil analisis instrument yang disebarkan dalam uji coba, 10 butir pertanyaan yang diajukan kepada responden adalah valid, dimana mempunyai korelasi yang lebih besar daripada nilai kritisnya pada taraf signifikansi 5\%, $\mathrm{n}=10$ dengan $\mathrm{t}$ tabel $=0.632$. Perhitungan lebih rinci disajikan pada lampiran. 


\section{Uji Reliabilitas}

Tabel 3.10 Hasil Perhitungan Reliabilitas Kuesioner

\begin{tabular}{|c|c|}
\hline \multicolumn{2}{|c|}{ Reliability Statistics } \\
\hline $\begin{array}{l}\text { Cronbach's } \\
\text { Alpha } \\
\end{array}$ & $\mathrm{N}$ of Items \\
\hline .841 & 10 \\
\hline
\end{tabular}

Setelah data yang diperoleh valid maka dilanjutkan dengan uji reliabilitas. Reliabilitas adalah konsistensi dari serangkaian pengukuran atau serangkaian alat ukur. Uji reliabilitas digunakan untuk mengukur tingkat kekonsistenan tanggapan responden terhadap item pernyataan angket berdasarkan pemahaman responden terhadap pertanyaan yang diajukan. Uji reliabilitas dilakukan dengan menggunakan rumus "Alfa Cronbach".

Pengujian reliabilitas kuesioner diperoleh nilai 0.841 yang berarti bahwa ke 10 pertanyaan memiliki tingkat reliabilitas yang tinggi, sehingga dapat digunakan sebagai instrument pengumpulan data bagi penelitian. Perhitungan lebih rinci disajikan pada lampiran.

Hasil uji reliabilitas tes yang menggunakan KR20 pada penelitian ini dikategorikan sedang karena koefisien reliabilitas-nya adalah 0.781. Perhitungan dapat dilihat pada lampiran.

\section{Uji Normalitas}

Uji Normalitas bertujuan untuk mengetahui normal atau tidaknya distribusi data. Untuk itu sebelum menggunakan teknik parametis kenormalan data harus diuji terlebih dahulu dengan menggunakan Uji Lilliefors, selanjutnya harga Lilliefors hitung tersebut dibandingkan dengan harga tabel Lilliefors. Harga $\mathrm{L}_{\text {tabel }}$ ditentukan taraf signifikansi $5 \%$. Data terdistribusi normal apabila $\mathrm{L}_{\text {hitung }} \leq \mathrm{L}_{\text {tabel }}$. Untuk data yang berdistribusi normal maka dapat digunakan teknik statistik parametis. 
Tabel 3.11 Uji normalitas

One-Sample Kolmogorov-Smirnov Test

\begin{tabular}{|c|c|c|}
\hline & Variabel X & Variabel Y \\
\hline $\mathrm{N}$ & 50 & 50 \\
\hline $\mathrm{N}$ o $\mathrm{r}$ m a 1 & 38.4600 & 72.8000 \\
\hline $\begin{array}{ll}\text { Parameters }^{\mathrm{a}, \mathrm{b}} & \mathrm{S} \mathrm{t} \mathrm{d} . \\
& \text { Deviation }\end{array}$ & 6.64926 & 9.90568 \\
\hline M $\quad$ o $\quad s \quad t$ Absolute & .118 & .109 \\
\hline Extrem e Positive & .069 & .118 \\
\hline Differences Negative & -.118 & -.109 \\
\hline Kolmogorov-Smirnov Z & .118 & .109 \\
\hline Asymp. Sig. (2-tailed) & $.081^{\mathrm{c}}$ & $.079^{\mathrm{c}}$ \\
\hline
\end{tabular}

a. Test distribution is Normal.

b. Calculated from data.

c. Lilliefors Significance Correction

Data diatas menunjukkan bahwa nilai variabel $\mathrm{x}$ dan variabel y menunjukkan 0.118 $<0.125$ dan $0109<0.125$ ( $\left.\mathrm{L}_{\text {hitung }} \leq \mathrm{L}_{\text {tabel }}\right)$. Oleh karena itu nilai normalitas kedua variabel lebih rendah dari nilai Ltabel maka data yang di distribusikan adalah normal.

\section{Uji Homogenitas}

Menurut Sugiyono (2010) Uji Homogenitas bertujuan untuk mengetahui homogen atau tidaknya distribusi dua kelompok data. Jika kedua kelompok mempunyai varians yang sama maka kelompok tersebut dinyatakan homogen.

Tabel 3.12 Uji homogenitas

Test of Homogeneity of Variances

Kemampuan Membaca Pemahaman

\begin{tabular}{|c|r|r|c|}
\hline $\begin{array}{c}\text { Levene } \\
\text { Statistic }\end{array}$ & df1 & \multicolumn{1}{c|}{ df2 } & \multicolumn{1}{c|}{ Sig. } \\
\hline 11.975 & 13 & 28 & .212 \\
\hline
\end{tabular}

Berdasarkan hasil SPSS di atas diketahui bahwa nilai signifikansi variabel Kemampuan Membaca Pemahaman (Y) berdasarkan variabel Motivasi Belajar (X) = $0.212>0.05$, artinya data variabel Kemampuan Membaca Pemahaman (Y) berdasarkan variabel Motivasi Belajar (X) mempunyai varian yang sama. 


\section{Hipotesis}

Tabel 3.13 Hasil Perhitungan Hipotesis

Coefficients $^{\mathrm{a}}$

\begin{tabular}{|c|c|c|c|c|c|}
\hline \multirow[b]{2}{*}{$\begin{array}{llllll} & \mathrm{o} & \mathrm{d} & \mathrm{e} & \mathrm{l}\end{array}$} & \multicolumn{2}{|c|}{$\begin{array}{l}\text { Unstandardized } \\
\text { Coefficients }\end{array}$} & \multirow{2}{*}{$\begin{array}{c}\text { Standardized } \\
\text { Coefficients } \\
\text { Beta }\end{array}$} & \multirow[b]{2}{*}{$\mathrm{T}$} & \multirow[b]{2}{*}{ Sig. } \\
\hline & B & $\begin{array}{l}\text { Std. } \\
\text { Error }\end{array}$ & & & \\
\hline 1 (Constant) & .282 & 5.105 & & .055 & .036 \\
\hline $\begin{array}{l}\text { Motivasi } \\
\text { Belajar }\end{array}$ & 1.004 & .131 & .742 & 7.674 & .003 \\
\hline
\end{tabular}

a. Dependent Variable: Kemampuan Membaca Pemahaman

Sumber : data diproses menggunakan SPSS 22.0

Hasil dari uji Hipotesis ini sendiri adalah t hitung $>t$ tabel dengan nilai sebesar $7.674>1.67(\mathrm{dk}=48)$. Hasil pengujian menunjukkan $\mathrm{t}$ hitung $>\mathrm{t}$ tabel yang artinya hal ini menunjukkan adanya pengaruh signifikan pada motivasi belajar terhadap kemampuan membaca pemahaman mahasiswa STBA-PIA semester V pada taraf signifikan 5\%. Ha diterima Ho ditolak.

\section{Pembahasan}

Ramdhan dan Harsono (2015) melakukan penelitian tentang motivasi belajar terhadap prestasi belajar mahasiswa program PJJ Telkom University tahun akademik 2013/2014 dengan dengan hasil penelitian dan analisis menunjukkan bahwa variabel motivasi belajar memiliki pengaruh yang signifikan terhadap variabel prestasi belajar, dimana motivasi belajar memiliki pengaruh persentase sebesar $13 \%$ dan sebesar $87 \%$ dipengaruhi oleh variabel-variabel lain yang tidak diteliti oleh penelitian ini. Seperti yang diungkapkan oleh Nashar (2004:11), Motivasi belajar yang dimiliki peserta didik dalam setiap kegiatan pembelajaran sangat berperan untuk meningkatkan prestasi belajar peserta didik dalam mata pelajaran tertentu. Sedangkan hasil penelitian penulis menunjukan bahwa Motivasi belajar terhadap Kemampuan Membaca Pemahaman memiliki pengaruh yang signifikan dengan taraf 5\%. Dengan motivasi integratif memiliki pengaruh lebih besar sebesar $50.8 \%$ dibandingkan dengan motivasi instrumental sebesar $49.2 \%$ dalam penelitian ini. Dimana motivasi belajar memiliki pengaruh sebesar 55\% terhadap kemampuan membaca pemahaman dan sebesar $45 \%$ dipengaruhi oleh variabel-variabel 
lain yang tidak diteliti oleh penelitian ini. Dalam hal ini, hasil penelitian Ramdhan dan Harsono dengan hasil penelitian penulis saling mendukung tentang pengaruh motivasi belajar.

\section{Daftar Pustaka}

Alexander, J.E. (1983). Teaching Reading. Boston: Scott Foresman and Company.

Nashar, H. (2004). Peranan Motivasi \& Kemampuan Awal. Jakarta: Delia Press

Ramdhan, M.Y., dan Harsono, L.D. (2015). Pengaruh Motivasi Belajar terhadap Prestasi Belajar Mahasiswa Telkom University Program Pendidikan Jarak Jauh Tahun Akademik 2013/2014. E-Proceeding of Management. 2(1), 156-161.

Rubin. (1982). A Practical Approach to Teach Reading. Boston: Allyn and Bacon

Sugiyono. (2009). Metode Penelitian Kuantitatif dan Kualitatif. Bandung: CV.Alfabeta.

Wei, M. (2007). Wàiguó liúxuéshēng hànyǔ xuéxí dòngjī jí yǔ chéngjī jiān guānxì de yánjiū. Dōngběi shīfàn dàxué shuòshì xuéwèi lùnwén. 